\title{
Patra Punggel dalam Telaah Konsep Penciptaan Seni Visual
}

\author{
Nyoman Suardina, I Wayan Suardana, I Nyoman Laba \\ Program Studi Kriya, Fakultas Seni Rupa dan Desain \\ Institut Seni Indonesia Denpasar \\ Jl. Nusa Indah, Denpasar, Bali \\ Tlp. 081239344817, E-mail: bais.sliwah@gmail.com
}

\begin{abstract}
Patra Punggelis a Balinese decoration that holds important knowledge to be explored. This assumption is the basis of interest in researching Patra Punggel. The problem is, "What is the concept of creating past kriyawan in creating Patra Punggelwhich is unique to the Balinese people?" The purpose of this study is to look for the symptoms of intertextuality as a simulation of the concept of art creation, which can be referred to as the concept of creating contemporary visual arts. The description of each object identified is the method used to reveal the process of the formation of Patra Punggel. Intertextuality is used as an approach, so that every text that is read from the constituent material to a new form and has a new meaning, is a concept finding. The sample of the research object was determined purposively, by determining the previously known characteristics related to the form of Patra Punggel. The stylization process from the initial form of the material to the complete Patra Punggelmotif is the focus of this study. Written information on research results is useful for students to be used as a reference in making the concept of creating art in the Final Project.
\end{abstract}

Keywords: Patra Punggel, Intertextuality, Concept of Visual Art Creation

\begin{abstract}
ABSTRAK
Patra Punggel adalah ragam hias Bali yang menyimpan pengetahuan penting untuk digali proses kemunculannya. Asumsi ini menjadi dasar ketertarikan untuk meneliti Patra Punggel, dengan Permasalahan, "Apa dasar konsep kriyawan masa lalu dalam menciptakan Patra Punggel yang unik bagi masyarakat Bali?" Tujuan penelitian ini untuk mencari gejala intertekstualitas sebagai sebuah simulasi konsep penciptaan seni, yang dapat dirujuk sebagai konsep penciptaan seni visual masa kini. Deskripsi setiap objek yang teridentifikasi merupakan metode yang digunakan untuk mengungkap proses terbentuknya Patra Punggel. Intertekstualitas digunakan sebagai pendekatan, sehingga setiap teks yang terbaca dari materi pembentuk hingga menjadi bentuk baru dan memiliki makna baru, menjadi temuan konsep dalam penelitian ini. Sampel objek penelitian ditentukan secara purposive, dengan menetapkan ciri yang diketahui sebelumnya terkait dengan bentuk Patra Punggel. Fokus kajian ini adalah proses stilirisasi dari bentuk materi awal, sampai menjadi motif Patra Punggel yang utuh. Penelitian ini akan sangat bermanfaat bagi mahasiswa untuk dijadikan rujukan dalam membuat konsep penciptaan seni selanjutnya.
\end{abstract}

Kata Kunci: Patra Punggel, Intertekstualitas, Konsep Penciptaan Seni Visual

\section{PENDAHULUAN}

Banyak penelitian yang telah dilakukan kalangan akademisi mengenai pepatran secara umum yang berkembang di Bali, dan khususnya Patra Punggel yang menjadi objek penelitian ini. I Wayan Setem (2021) 
menyatakan Patra Punggel adalah ornamen tradisional Bali yang mengambil bentuk dasar liking paku sejenis flora dengan lengkung daun mudanya. Bagian motif Patra Punggel ada yang disebut batun poh (biji mangga), kuping guling (telinga babi), dan util sebagai identitas. Patra pungggel merupakan motif hias yang banyak digunakan untuk menghias bidang tertentu yang dikombinasi dengan bentuk kekarangan (ornamen dari jenis binatang). Makna filosofis Patra Punggel yakni menjaga keharmonisan ekosistem untuk ketahanan ekologi yang telah memberikan kesejukan, keindahan, dan kenyamanan (Setem, 2021, hlm. 368). I Nyoman Gelebet (1982) menguraikan Patra Punggel adalah motif hias Bali yang merupakan stilirisasi dari bentuk liking paku yaitu sejenis flora yang hidup di semak belukar. Bagian Patra Punggel terdiri dari batun poh (biji mangga), ampas nangka (isi nagka), janggar siap (mahkota ayam), kuping guling (telinga babi), dan util sebagai identitas. Pola patern Patra Punggel merupakan pengulangan dengan irama lengkung bolak balik atau searah, dapat pula dengan pola pengembang untuk bidang-bidang lebar yang dikombinasi dengan pepatran lainnya (Gelebet, 1982, hlm. 243). Pepatran adalah motif hias tradisional Bali yang merupakan stilirisasi dari bentuk tumbuh-tumbuhan. Patra berasal dari bahasa sansekerta yang berarti "daun" atau "urat". Tumbuhan yang disetilirisasi menjadi pepatran, ada yang diambil secara utuh maupun diambil beberapa bagian saja yang dianggap menarik untuk dijadikan motif hias. Motif hias ini biasanya diterapkan pada bidang yang lebih lebar karena motifnya terdiri dari berbagai rangkian seperti dauh, buah, bunga, ranting, dan yang lainnya. Hal yang termasuk pepatran adalah: Patra Punggel, Patra Samblung, Patra Sari, Patra Ulanda, Patra Cina, Patra Banci (Karuni, 2013, hlm. 197). Patra Punggel (penggalan) adalah gabungan dari beberapa unsur tumbuhtumbuhan dan unsur binatang yang disusun menjadi satu motif baru. Motif Patra Punggel dapat dipakai untuk motif pada liking paku, bentala, dan geber pada bingkai. Motif ini tidak mempunyai makna simbolis, tetapi hanya sebagai motif pada pola-pola tertentu dengan fungsi menghias (Sika, 1983, hlm. 150). Gede Satria Budi Utama (2012) menjelaskan Patra Punggel adalah penggabungan dari beberapa unsur-unsur tumbuh-tumbuhan dan binatang yang disusun menjadi motif baru. Merupakan rangkaian dari ampas nangka, batun poh, kuping guling, kepitan, dan util. Punggel berarti pucuk daun baru tumbuh dari bekas tunas yang dipotong, kemudian dipergunakan sebagai hiasan dengan irama bolak-balik menurut kesenangan senimannya (Utama, 2012, hlm. 129)

Secara spesifik penelitian tersebut telah berhasil dengan baik dalam mendokumentasikan dan mendeskripsikan keberadaan berbagai jenis ragam hias/ ornamen tersebut. Informasi pengetahuan yang didapat dari hasil penelitian tersebut, baik yang telah dipublikasi dalam bentuk jurnal, ataupun buku teks. Penulis tertarik pada bentuk Patra Punggel yang keberadaannya sangat unik. Berdasarkan penjelasan berbagai sumber bahwa Patra Punggel dibentuk dari unsur tumbuhan dan binatang yang ada dalam lingkungan alam budaya Masyarakat Bali. Secara empiris, jika diamati unsur 
pembentuk Patra Punggel seakan sangat akrab sebagai benda yang dikenal dalam keseharian, seperti batun poh (biji mangga), ampas nangka (bagian pembungkus daging buah nangka), kepitan (pelepah kuncup pada tanaman), kakulan (keong sawah), janggar siap (jengger ayam), kuping guling (telinga babi guling), dan util (bagian ujung daun pakis muda). Jika diperhatikan di alam, semua unsur ini tidak pernah ada hubungan atau konteks apapun, namun di tangan seniman masa lalu dapat berubah menjadi suatu hal yang sangat indah, membentuk susunan struktur yang kini diwariskan dengan nama Patra Punggel. Bentuk Patra Punggel memiliki pakem yang diakui masyarakat secara turun temurun (tradisi komunal). Pakem adalah sebuah kesepakatan tentang pengakuan suatu persepsi, utamanya penyamaan persepsi para seniman, ini merupakan ciri masyarakat komunal dalam berkesenian (Mudarahayu, 2021, hlm. 94).

Asumsi yang paling penting terkait penelitian ini adalah adanya gejala interteks yang menjadi roh dalam pikiran seniman Bali masa lalu dalam berkesenian. Sebagai contoh, ornamen Patra Punggel dibentuk dari berbagai unsur yang sebelumnya tidak saling berkaitan, namun dalam bentuk barunya unsurunsur tesebut memiliki makna baru sebagai ornamen yang memiliki nilai estetika. Hal ini merupakan aspek ontologis masyarakat Bali, khususnya para kriyawan masa lalu dalam menanggapi alam dan lingkungan sekitar, kemudian menjadikannya benda-benda yang bermanfaat. Aspek ontologis ini menurut Kudiya, didasari oleh sikap tanggap yang dapat menggugah potensi bahwa manusia itu mahluk yang kreatif memiliki akal dan strategi berfikir (Kudiya, 2021, hlm. 95).

Patra Punggel sebagai warisan bentuk ragam hias, tentu dihasilkan melalui proses desain, meskipun melalui proses yang sederhana. Para seniman masa lampau, dalam berkesenian selalu bersifat komunal, demikian juga halnya dengan proses terbentuknya suatu ragam hias, dihasilkan dari kumpulan pemikiran seniman. Terbentuknya suatu ragam hias melalui proses yang panjang, yang melibatkan berbagai pemikiran para seniman pada zamannya, hingga ragam hias mencapai kesempurnaan bentuknya. Hendriyana menjelaskan bahwa, proses budaya kreatif seni kriya dan desain tidak terlepas dari ide yang berhubungan dengan dinamika kelompok masyarakat baik bersifat personal ataupun komunal, artinya dalam setiap zaman akan selalu ada dialektika terhadap segala sesuatu yang menyangkut perubahan kehidupan, termasuk dalam bidang desain. Setiap dialektika akan membentuk respon-respon dan daya cipta masyarakat tertentu, sehingga mewujudkan tindakan yang menghasilkan produk atau karya yang dihasilkan dari masyarakatnya. Hal inilah yang menyebabkan sebuah desain atau rancangan akan mengikuti pola dinamis, sesuai dengan kebutuhan mode pada zamannya. Sesederhana atau sekompleks apapun produk kriya manusia tentulah merupaan hasil dari perwujudan gagasan melalui proses tindakan (Hendriyana, 2021, hlm. 402).

Intertekstualitas, sebagai sebuah teori yang dicetuskan Julia Cristeva merupakan bidang semiologi post-strukturalisme yang sering dirujuk kalangan peneliti untuk 
memecahkan berbagai permasalahan yang terdapat dalam objek yang sedang diteliti. Hal ini menjadi motivasi tersendiri untuk menggunakan intertekstualitas sebagai pendekatan dalam menelaah konsep kriyawan masa lalu dalam berkesenian, khususnya dalam menciptakan Patra Punggel. Pertanyaan kuncinya adalah “Gejala apa yang terjadi pada konsep penciptaan Patra Punggel oleh kriyawan Bali di masa lalu?"

Penelitian ini ingin membuktikan bahwa terciptanya wujud ragam hias Patra Punggel dapat diukur dengan teori intertekstualitas dan hal ini dapat digunakan rujukan konsepsional bagi mahasiswa yang akan menciptakan karya seni tugas akhir. Dengan demikian, penelitian ini sangat penting agar mahasiswa segera mendapatkan referensi dan lebih mudah menemukan konsep dan metode dalam proses penciptaan karya.

Penelitian mengenai ragam hias Patra Punggel yang ditinjau khusus dari perspektif intertekstualitas belum pernah dilakukan. Kontekstual penelitian ini dengan tujuan khusus yang ingin dicapai yakni pembuktian gejala intertekstualitas pada proses penciptaan Patra Punggel, serta mengembangkan konsepsi penciptaan seni dari keterkaitan ini, yang bermanfaat bagi mahasiswa yang akan menciptakan karya seni tugas akhir. Dengan demikian, state of the art sangat penting sebagai dasar pemikiran untuk memosisikan penelitian ini berbeda dengan penelitian yang pernah dilakukan, serta dapat berfungsi sebagai analisis dan memperkaya pembahasan penelitian.

Susanto (2011) menjelaskan bahwa intertekstualitas merupakan bergantungan satu teks dengan teks-teks sebelumnya, dalam bentuk persilangan berbagaikutipandanungkapan-ungkapannya, yang satu sama lain saling mengisi (Susanto, 2011, hlm. 198).

Piliang, (2003, hlm. 133-134) menjelaskan bahwa istilah intertekstualitas (intertertuality) pertama kali diperkenalkan oleh Julia Kristeva, seorang pemikir postrukturalis Prancis, dalam bukunya Revolution in Poetic Language dan Desire in Language: A Semiotic Approach to Literature and Art. Piliang menggarisbawahi dalam kedua buku Kristeva, istilah intertekstualitas merupakan konsep kunci dari paham post-rukturalisme, yang memiliki model berpikir yang berbeda dengan struktur, sinkronik, dan bersistem dari paham strukturalis.

Ratna (2018, hlm. 298-327) menyatakan bahwa interteks berawal dari teori sastra dan di dalamnya dikenal istilah hypogram, sebuah istilah yang dikemukakan Riffaterre terkait teks tersembunyi yang dirujuk oleh naskah yang sedang dibaca. Interteks dipandang memiliki pengertian jamak, di mana dalam hubungan beberapa unsur seperti sebuah tenunan, jaringan, sehingga interteks dapat disebutkan sebagai hubungan atas hubungan, jaringan atas jaringan, sehingga manipulasi makna sangat memungkinkan terjadi melalui hubungan interteks. Interteks, sesuai dengan karakter paham post-strukturalis yang melahirkannya pada umumnya memadukan analisis intrinsik dan ekstinsik karya dan aspek-aspek kebudayaan secara luas yang selama ini tersembunyi dan terpinggirkan.

Siwalatri menjelaskan dalam artikel pada Journal of Basic and Applied Scientific 
Research dengan judul "Meaning of Ornament in Balinese Traditional Architecture" bahwa:

Traditional Balinese ornaments are divided into three major groups, namely the ornaments that take the form of flora, fauna and nature (1). This grouping is based on the form expression of ornaments as a form of metaphor or stylistik of the forms that exist in the environment, but there are also forms of imagination of artists drawn from stories from puppetary, myth or legend. (Siwalatri, 2012, hlm. 7122-7123).

Karakter Ornamen Bali dikelompokkan dalam tiga kelompok besar, yaitu bentuk flora, fauna, dan alam. Pengelompokan ini didasarkan pada ekspresi wujud ragam hias sebagai wujud metafora atau stilistik dari bentuk-bentuk yang ada di lingkungan, tetapi ada juga bentuk-bentuk imajinasi seniman diambil dari cerita dari pewayangan, mitos, atau legenda.

Penamaan masing-masing ornamen diberikan berdasarkan beberapa pertimbangan antara lain berdasarkan referensi bentuk asli dari ornamen seperti Patra Samblung dan Patra Punggel yang mewakili tanaman lokal, atau menekankan pada bagian tertentu dari ornamen yang diwakili (Patra Sari, Patra Wangga penekanan pada serbuk sari dari bunga). Klasifikasi dan penamaan ornamen secara umum didasarkan pada bentuk yang dijadikan acuan imitasi atau metafora.

Suardana dalam sebuah laporan penelitian (2012) menjelaskan bahwa pada dasarnya Patra Punggel merupakan gubahan dari lengkung pohon paku (Pakis) yang dikombinasi dengan elemen motif hias lainnya, sehingga menjadi motif hias yang cukup menarik. Dilihat dari etimologinya "punggel" berasal dari bahasa Bali "a punggel" yang artinya penggalan satu tangkai tumbuhan yaitu tangkai daun paku yang masih muda dan melengkung. Dari lengkungan ini divariasi lagi, sehingga menjadi motif hias yang utuh. Patra Punggel terdiri dari beberapa unsur motif yaitu: ampas nangka, batun poh, janggar siap, kuping guling, util, dan kepitan. Ampas nangka adalah bagian isi cempedak yang tidak bisa dimakan selain batunya. Batun poh yaitu biji mangga yang telah disetilir yang dibuat melengkung di atas ampas nangka. Batun poh merupakan elemen paling pokok dalam Patra Punggel. Janggar siap adalah daging yang ada di atas kepala ayam merupakan elemen yang berada diantara ampas nangka dan batun poh. Kuping guling adalah gubahan dari daun telinga babi yang ditempatkan di atas janggar siap. Kuping guling ini merupakan daunnya Patra Punggel karena bentuknya menyerupai daun waru. Util adalah segala sesuatu yang ada dalam motif hias tradisional Bali yang bentuknya melingkar. Util sebenarnya sulur yang terdapat dalam tumbuhan yang bentuknya melingkar. Kepitan adalah daun muda yang baru mau keluar dan masih kuncup. Kepitan ini biasanya membungkus batun poh. (Suardana, 2012, hlm. 20-21).

Jika diamati lebih dalam penjelasan di atas, transformasi yang terjadi dari unsur alam menjadi karya seni (Patra Punggel) dalam konteks ini masih menyisakan misteri, dan sangat tepat jika diteliti dan dikaji dengan pendekatan intertekstualitas. Mujiono (2016) menjelaskan, bahwa logika intertekstualitas sebagai bangunan teori dalam masab post moderenisme, boleh jadi menggandeng dekonstruksi, dan untuk memunculkan 
makna dalam bentukan barunya, simulasi sebagai penegasan opini merupakan sesuatu yang wajar. Pendekatan interteks ini digunakan untuk membuktikan asumsi yang menyebutkan bahwa Patra Punggel terbentuk dari inspirasi unsur alam (bagian flora dan fauna) seperti yang telah diuraikan.

\section{METODE}

Metode adalah cara yang digunakan dalam pengumpulan data untuk mencapai tujuan dalam penelitian ini. Metode penelitian sangat terkait dengan langkah-langkah yang harus dilakukan untuk memperoleh hasil penelitian yang objektif dan ilmiah, serta memudahkan dalam menganalisa data dan mengambil kesimpulan.

Metode yang digunakan dalam penelitian ini adalah metode deskriptif kualitatif yaitu pengamatan, wawancara, dan penelaahan dokumen. Metode ini digunakan karena menyajikan secara langsung hubungan antara peneliti dan responden, lebih peka dan lebih dapat menyesuaikan diri pola-pola nilai yang dihadapi (Moleong, 2013, hlm. 10). Metode kualitatif memberikan perhatian pada kedalaman informasi, menggali makna di balik gejala, dan mementingkan studi kasus, serta hasilnya lebih bersifat narasi melalui kata-kata (Ratna, 2010, hlm. 98).

Lokasi penelitian berada di wilayah Kabupaten Gianyar, Patra Punggel sebagai ragam hias tersebar luas di semua kecamatan dan sebagian besar masyarakat mengaplikasikannya sebagi ornamentasi pada bangunan suci/tempat tinggal. Penelitian seni lazimnya memiliki dua sumber data yaitu pertama Patra Punggel secara fisik sebagai ukiran pada kayu/batu padas, yang berkaitan dengan bentuk. Kedua faktor yang membentuk terciptanya Patra Punggel, yakni inspirasi dari unsur bentuk tumbuhan dan binatang. Kedua sumber data ini umumnya disebut sebagai faktor intraestetik dan faktor ekstraestetik (Rohidi, 2011, hlm. 75).

Populasi dalam penelitian ini adalah pelinggih pada pura Puseh Desa, Silakarang, Desa Singapadu Kaler, Kecamatan Sukawati, Kori Agung pada pura Dadia Tangkas Kori Agung, Silakarang, Desa Singapadu Kaler, Kecamatan Sukawati pelinggih pada pura Tirta Empul, Silakarang, Desa Singapadu Kaler, Kecamatan Sukawati, pelinggih pada pura Dalem, Banjar Bya, Desa Keramas, Kecamatan Blahbatuh, rumah tempat tinggal di Banjar Nyuh Kuning, Desa Mas, Kecamatan Ubud Kabupaten Gianyar, dan rumah tempat tinggal di Banjar Sakih, Desa Ketewel, Kecamatan Sukawati, Kabupaten Gianyar. Sedangkan sampelnya adalah ragam hias Patra Punggel yang dianggap dapat mewakili wilayah tersebut. Dalam penelitian ini pengambilan sampel bukan melalui jumlah atau sampel acak, melainkan digunakan teknik Purposive Sampling (sampel bertujuan), dengan alasan bahwa setiap sampel memiliki kreteria seperti yang dibutuhkan dalam penelitian.

Sebagai upaya untuk mendapatkan data penelitian secara maksimal, dilakukan melalui sumber referensi, observasi, dan wanwancara dengan seniman/budayawan yaitu I Wayan Mudana (Br. Silakarang, Desa Singapadu Kaler, Kecamatan Sukawati, I Made Jana (Br. Bya, Desa Keramas, Kecamatan Blahbatuh, Gianyar), dan I Made Balik 
Riti (Br. Sakih, Desa Guwang, Kecamatan Sukawati, Gianyar). Dalam hal ini, juga dilakukan analisis terhadap unsur tanaman dan binatang yang digunakan sebagai objek/materi Patra Punggel. Dalam proses penelitian yang dilakukan lebih mengarah pada sifat eksploratif, karena bertujuan untuk menggambarkan keadaan atau status fenomena. Peneliti ingin mengetahui secara mendalam tentang penciptaan bentuk Patra Punggel dari persepektif intertekstualitas.

\section{HASIL DAN PEMBAHASAN}

Sampel ukiran Patra Punggel yang menjadi target penelitian di lokasi Pura Puseh Desa Br. Silakarang keseluruhannya berbahan batu padas. Silakarang merupakan salah satu pusat seni ukir batu padas di daerah Sukawati Gianyar yang telah berkembang sejak lama. Sumber informasi tertulis tentang awal mula munculnya seni ukir batu padas di Br. Silakarang belum ada. Aspek kesejarahan ini lebih banyak berdasarkan pada keterangan dari para tokoh seniman/kriyawan yang masih hidup di Silakarang. Tokoh Budayawan di Silakarang juga menyatakan bahwa sejarah seni ukir batu padas belum banyak yang menulis dalam bentuk penelitian.

Mengingat pentingnya aspek kesejarahan untuk menemukan dokumen dalam bentuk artefak tertua pada populasi sampel penelitian ini, maka mata rantai penghubung masa lalu hingga perkembangan saat ini sangat diperlukan untuk membantu mengungkap berbagai hal terkait perkembangan Patra Punggel yang bersifat fisik maupun nonfisik. Pelacakan sejarah ini dilakukan dengan meminta keterangan dari tokoh budayawan yang dianggap mengetahui tumbuhnya seni ukir batu padas di Silakarang. Kuntowijoyo menjelaskan, bahwa sumber sejarah menurut bahannya dapat dibagi menjadi dua, yaitu: sumber terulis dan tidak tertulis, atau dokumen dan artifact, selain itu, penulisan sejarah juga dapat dibangun dari sumber-sumber lisan atau ingatan orang dengan peristiwa-peristiwa yang pernah diketahui, harus dicari dengan sejarah lisan. (Kuntowijoyo, 2005, hlm. 95).

Seorang tokoh yang dianggap sebagai cikal bakal munculnya seni ukir batu padas di Silakarang adalah Pekak Sore. Beliau dilahirkan dan dibesarkan di Silakarang. Pekak Sore merupakan tokoh sentral seniman saat itu yang telah melahirkan pahatan ornamen pertama di Selakarang. Aktivitas mengukir pada awalnya sebagai wujud pengabdian kepada kepentingan agama. Dedikasi itu terlihat nyata pada bangunan Pura Puseh Desa yang diperkiraakan dilaksanakan pada tahun 1832. Pada bangunan pelinggih yang tampak paling tua yakni bangunan Kori Agung dan Gedong tampak dihiasi ornamen sederhana, dari persepektif ornamentasi masa sekarang dianggap sangat awal. Namun uniknya ornamentasi yang dipahatkan sudah menunjukkan berbagai jenis pepatran, di antaranya Patra Olanda, Patra Samblung, Patra Cina, dan Patra Punggel dalam bentuk yang masih sederhana.

Periode berikutnya suatu hal penting terjadi, perbaikan/pemugaran Kori Agung Pura Puseh Desa ini. Diperkirakan ada kegiatan gotong royong beberapa orang belajar memahat dibimbing oleh Pekak Sore. Hal ini dapat dilihat ada banyak model 
ukiran pada bagian-bagian bangunan Kori Agung tersebut. Dapat disimpulkan bahwa masyarakat Silakarang sangat tertarik dengan kegiatan mengukir, sehingga sebagian besar masyarakatnya menggantungkan hidupnya dari seni ukir, oleh sebab itu sampai sekarang, Silakarang terkenal sebagai basis ahli mengukir batu padas.

Pengumpulan data dilakukan melalui proses pendokumentasian sampel yang ada pada populasi yang telah ditentukan dengan mengamati objek penelitian. Pengamatan yang dimaksud adalah memerhatikan dan menentukan dengan cermat populasi objek, yaitu Pelinggih Pura dan Kori Agung/ Candi Bentar di lokasi penelitian yang memiliki ornamen sesuai dengan target yang diinginkan.

Pada bangunan Candi Bentar dan Kori Agung terdapat berbagai motif ukiran pepatraan, salah satunya adalah Patra Punggel yang umumnya dikombinasikan dengan kekarangan (stilasi dari kepala binatang/ makhluk ciptaan), seperti Karang Gajah (stilasi Kepala gajah), dan Karang Manuk (stilasi kepala burung).

Penerapan Patra Punggel pada candi kurung ini, tidak saja untuk menghias bidang datar tertentu, atau bidang dimensi yang dikombinasi dengan kekarangan, tetapi juga banyak dipakai sebagai hiasan pada patungpatung yang mencadi pelengkap hiasan candi kurung tersebut. Penerapan Patra Punggel pada patung biasanya untuk menghias busana dan atribut lainnya. Bentuk Patra Punggel yang unik sangat tepat juga diterapkan untuk menghias patung Dewa-dewa yang memiliki busana dan atribut yang khas. Untuk menghias patung

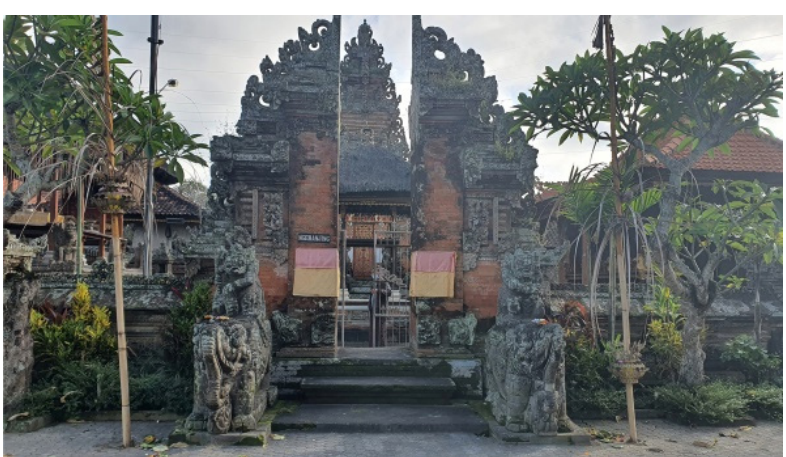

Gambar 1. Candi Bentar Pura Puseh Desa

Br. Silakarang, Singapadu Kaler, Sukawati (Sumber: I Nyoman Suardina, 2021)

Patra Punggel diterapkan dalam teknik seni ukir rendah, karena bentuknya relatif kecilkecil.

Berbagai teknik ukir digunakan dalam penerapan Patra Punggel pada candi kurung maupun candi bentar, yaitu teknik ukir datar, ukir sedang, ukir timbul, maupun teknik tembus. Teknik ukir datar (rendah) adalah tonjolan motif ukiran sangat tipis yang disebut dengan ukiran "tampak sida". Teknik ukir sedang adalah tonjolan motifnya tidak melebihi latar belakang, teknik ukir timbul adalah motif yang dibuat sangat menonjol, dan teknik ukir tembus adalah bagian latar belakang patra dibuat tembus (Sika, 1983, hlm. 60-61). Penggunaan teknik ukir ini tergantung pada bidang mana motif hias Patra Punggel itu itu diterapkan. Ragam hias yang diterapkan pada Pura Puseh Desa Br. Silakarang menggunakan teknik ukir sedang dan teknik ukir timbul

Bangunan candi yang ada di Desa Silakarang ini menyimpan dokumentasi sejarah, hal ikhwal bagaimana masyarakat di desa ini belajar membuat ukiran. Seperti yang telah disebutkan bahwa sekitar tahun 1832, I Pekak Sore (tokoh Undagi) desa saat itu membuat semacam workshop (pelatihan) 
kepada anak-anak muda yang berminat untuk menekuni pekerjaan mengukir dan siap untuk mengabdi membangun tempat suci untuk persembahyangan (Pura). Kegiatan ini telah menghasilkan generasi pengukir-pengukir handal di Desa Silakarang, di antara anak didik I Pekak Sore adalah I Tedun, I Rangkin, I Rinting, I Legud, dan I Lampias. Keahlian mengukir antara senior dan para anak didik tersebut tercermin dalam ukiran ragam hias yang ada pada bangunan Candi di Pura Puseh Desa Banjar Silakarang. Tampak berbagai corak model pahatan, meskipun dalam satu bentuk pepatran.

Pada bangunan candi dan pura di desa inilah terdapat ukiran Patra Punggel yang dipandang cukup tua, untuk menunjukkan bahwa bentuk pepatraan yang saat ini dikenal sebagai Patra Punggel dengan berbagai unsur pembentuknya sudah tercipta pada masa silam.

\section{Identifikasi Data Fisik}

Identifikasi yang dimaksudkan dalam penelitian ini adalah menentukan dan menetapkan identitas sampel penelitian yang dipilih dari populasi objek penelitian dan menggarisbawahi hal-hal yang dianggap penting terkait keberadaan motif Patra Punggel dalam objek penelitian.

Identifikasi ditampilkan dengan foto dokumentasi, berdasarkan petunjuk dan hasil wawancara dengan informan yang ahli dalam pembuatan maupun tentang kesejarahan di bidang ragam hias, serta memerhatikan beberapa referensi yang dianggap valid. Pada objek penelitian terdapat banyak jenis pepatran, termasuk Patra Punggel.

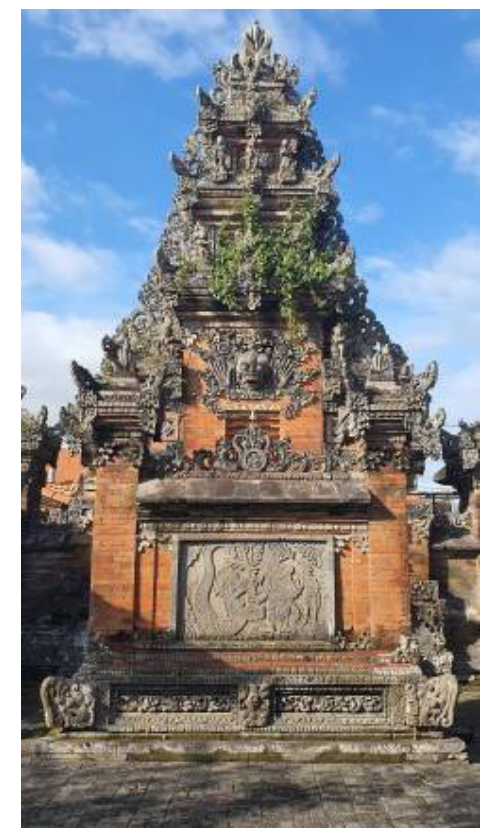

Gambar; 2. Kori Agung Pura Puseh Desa Br. Silakarang, Singapadu Kaler, Sukawati (Sumber: I Nyoman Suardina, 2021)

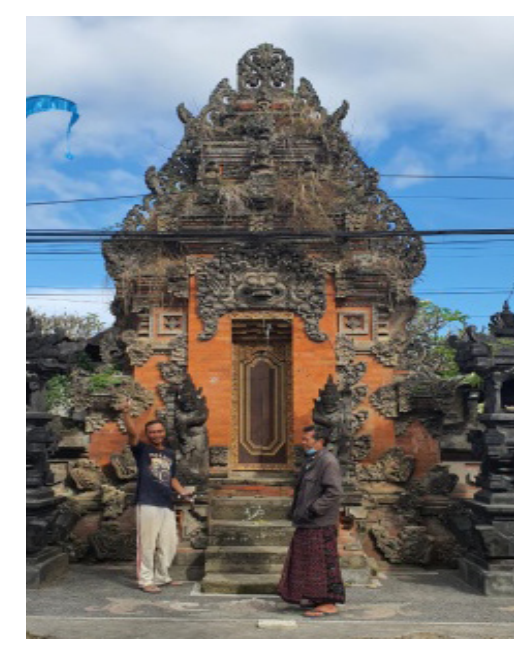

Gambar 3. Kori Agung Pura Dadia Tangkas Br. Silakarang, Singapadu Kaler, Sukawati (Sumber: I Nyoman Suardina, 2021)

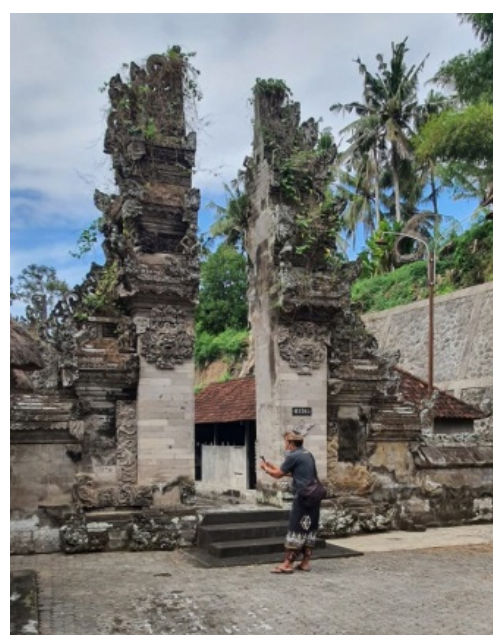

Gambar 4. Candi Bentar Pura Tirta Empul Br. Silakarang, Singapadu Kaler, Sukawati (Sumber: I Nyoman Suardina, 2021) 


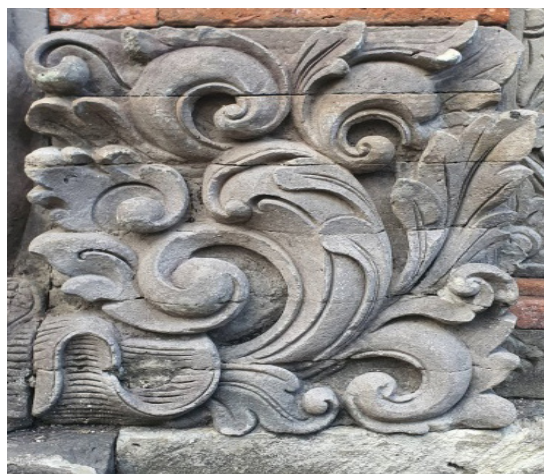

Gambar 5. Patra Punggel pada Kori Agung Pura Puseh Desa Br. Silakarang, Singapadu Kaler, Sukawati (Sumber: I Nyoman Suardina, 2021)

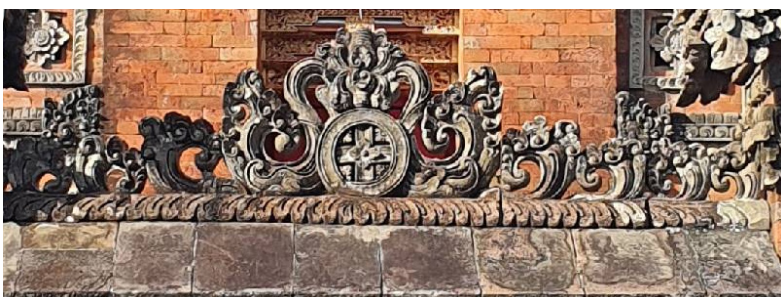

Gambar 6. Patra Punggel pada Aling-Aling Pura Puseh Desa Br. Silakarang, Singapadu Kaler, Sukawati (Sumber: I Nyoman Suardina, 2021)

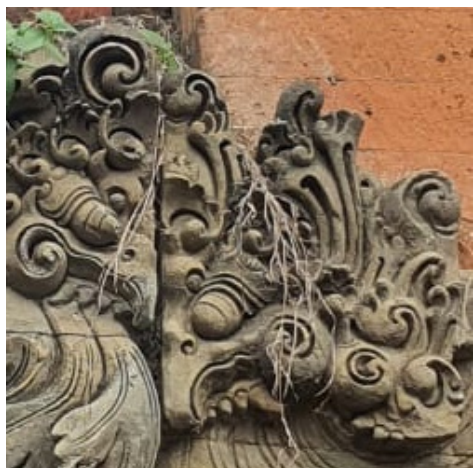

Gambar 7. Patra Punggel pada Kori Agung Pura Dadia Tangkas Koriagung Br. Silakarang, Singapadu Kaler, Sukawati

(Sumber: I Nyoman Suardina, 2021)

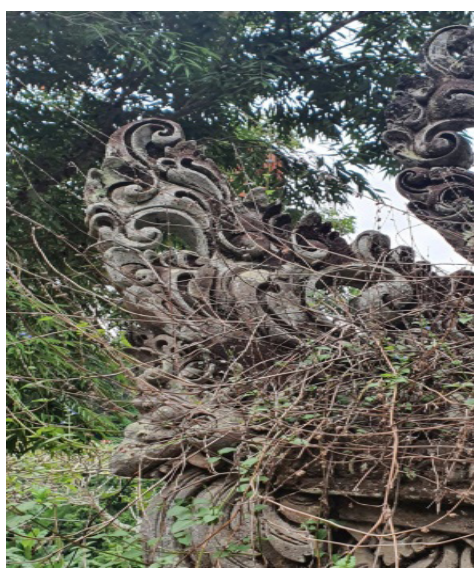

Gambar 8. Patra Punggel pada Candi Bentar Pura Tirta Empul Br. Silakarang, Singapadu Kaler, Sukawati (Sumber: I Nyoman Suardina, 2021)

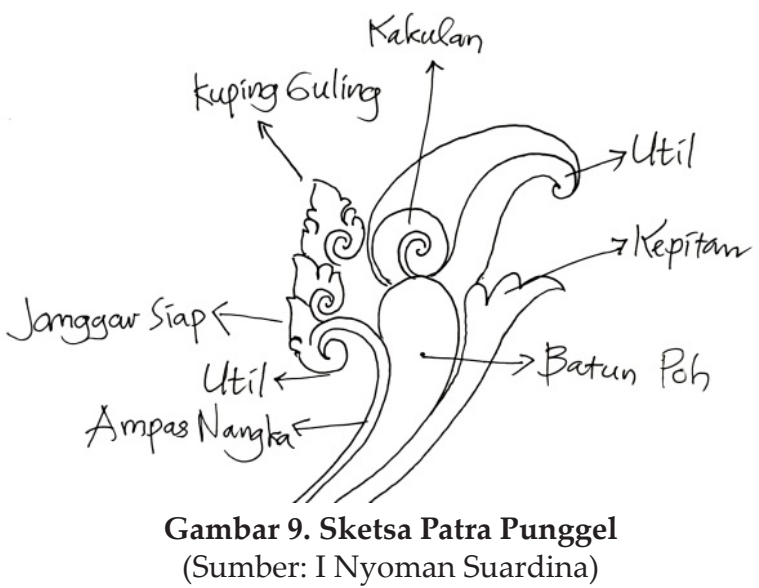

Gambar 5-8 adalah hasil pendokumentasian terhadap identifikasi data fisik keberadaan Patra Punggel pada objek penelitian yang terdapat di tiga lokasi, yakni Pura Puseh Desa, Pura Dadya Tangkas Kori Agung, dan Pura Tirta Empul, Desa Singapadu Kaler, Sukawati, Gianyar, Bali.

\section{Analisis}

Pengamatan mendalam telah dilakukan terhadap bentuk Patra Punggel yang ada pada objek yang diidentifikasi. Hasil pengamatan ini juga diperkuat dengan pendapat ahli, dalam hal ini budayawan dan praktisi dibidang ukir pepatran, khususnya Patra Punggel. Jika dikorelasikan dengan referensi yang ada, ada kesamaan persepsi maupun realitas bentuk Patra Punggel. Secara visual garis kontur Patra Punggel beserta keterangan nama-nama komponen pembentuknya dapat dilihat pada gambar 9 .

Berdasarkan keterangan nama-nama unsur pembentuk Patra Punggel tersebut, seperti yang ditulis pada beberapa referensi serta penjelasan dari informan terkait, Patra Punggel dibentuk dari penggabungan unsur binatang dan tumbuh-tumbuhan. Asumsi ini dapat dijelaskan dengan menerjemahkan 


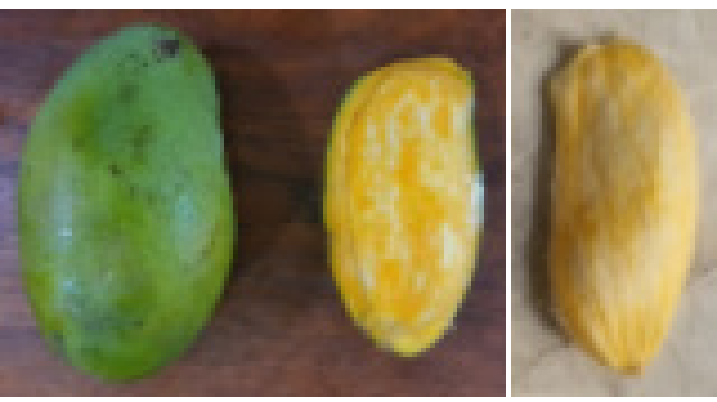

Gambar 10. Batun Poh (Biji Mangga) (Sumber: I Nyoman Suardina)

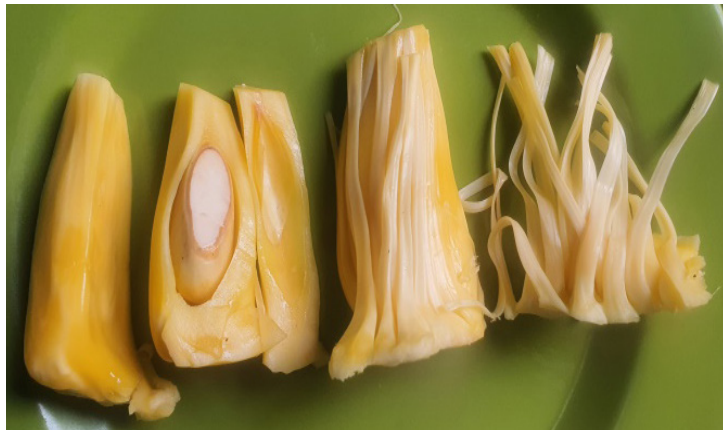

Gambar 11. Ampas Nangka

(Serabut pada daging buah nangka) (Sumber: I Nyoman Suardina)

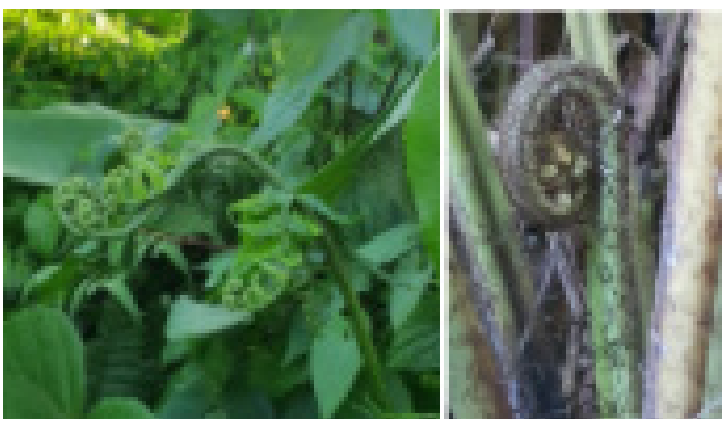

Gambar 12. Liking Paku/Util (daun pakis muda) (Sumber: I Nyoman Suardina)

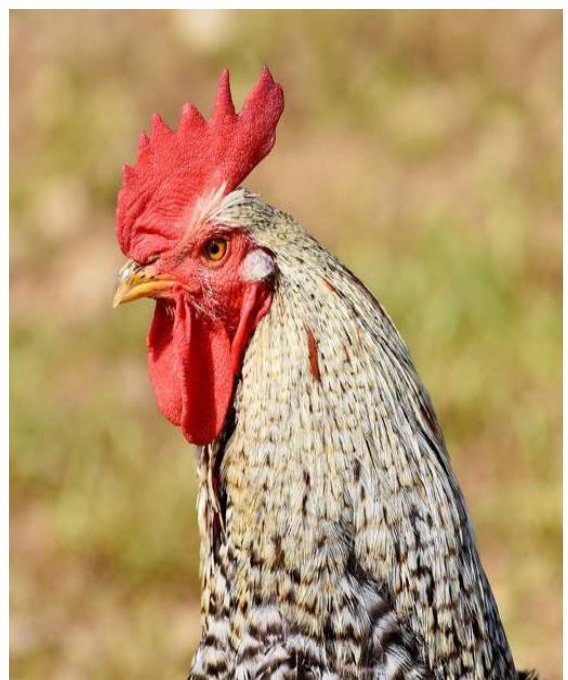

Gambar 13. Janggar Siap (Jengger Ayam Jago) (Sumber: I Nyoman Suardina)
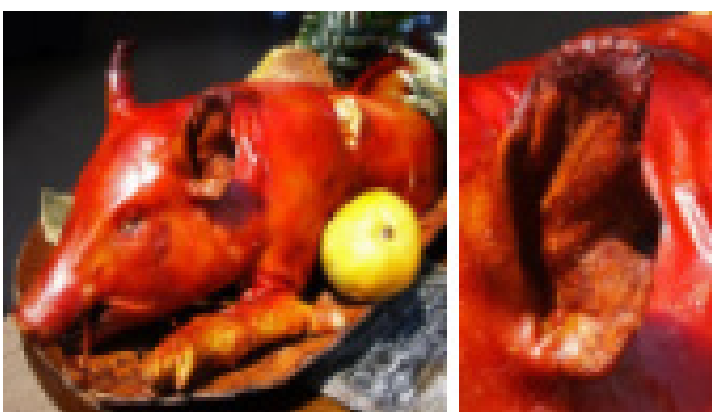

Gambar 14. Kuping Guling (Telinga Babi Guling) (Sumber: I Nyoman Suardina)

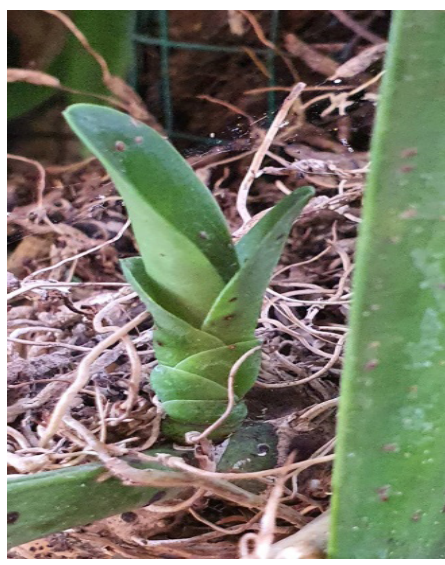

Gambar 15. Kepitan (Pelepah Daun/Tunas Muda) (Sumber: I Nyoman Suardina)

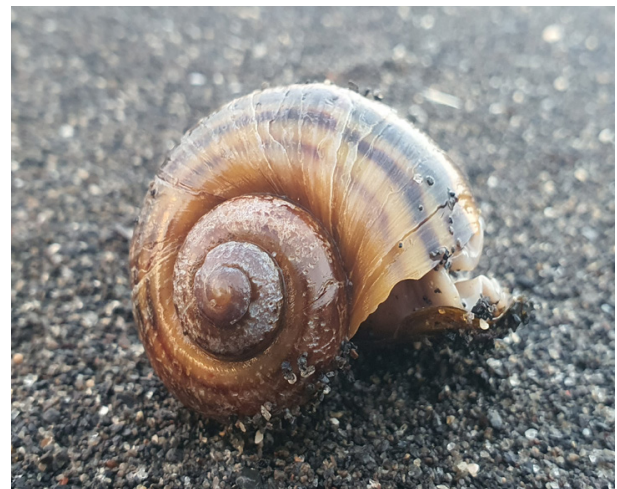

Gambar 16. Kakul (Keong Sawah)

(Sumber: I Nyoman Suardina)

kembali nama-nama unsur pembentuk tersebut melalui gambar asli sebagai berikut.

a. Batun Poh (Biji Mangga)

b. Ampas Nangka (serabut biji nangka)

c. Liking Paku/Util (daun pakis muda)

d. Janggar Siap (jengger ayam jago)

e. Kuping Guling (telinga babi guling)

f. Kepitan (Pelepah Daun/Tunas Muda)

g. Kakul (Keong Sawah)

Keseluruhan dari gambar tersebut merupakan unsur binatang dan tumbuh- 


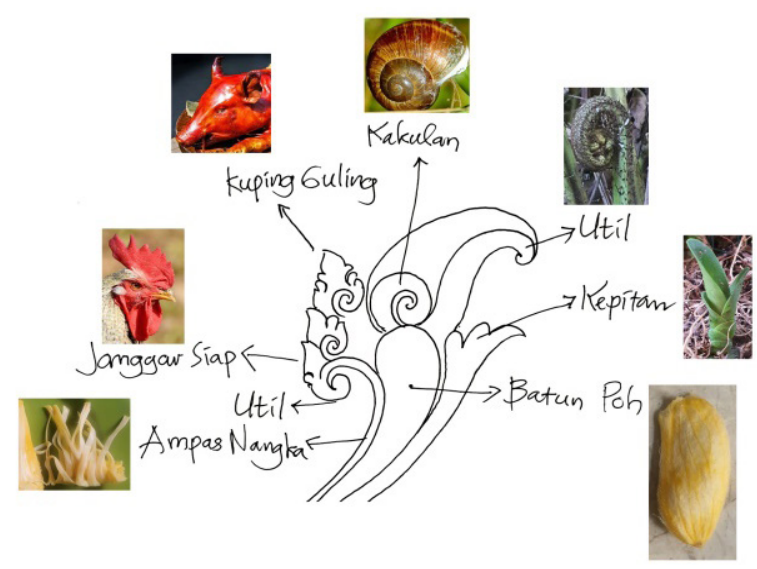

Gambar 17. Konstruksi Unsur-Unsur Sumber Inspirasi Patra Punggel (Sumber: I Nyoman Suardina)

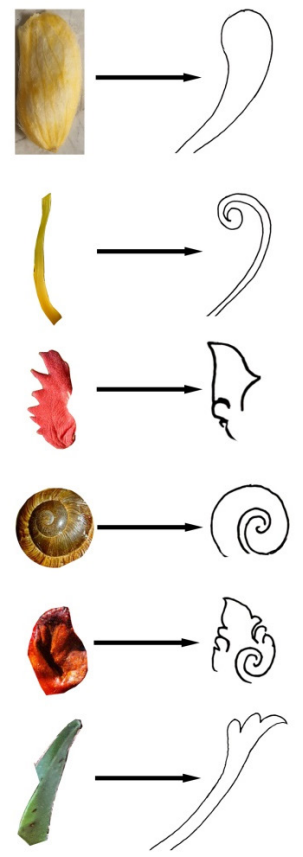

Gambar 18. Transformasi Unsur-Unsur Sumber Inspirasi Patra Punggel (Sumber: I Nyoman Suardina)

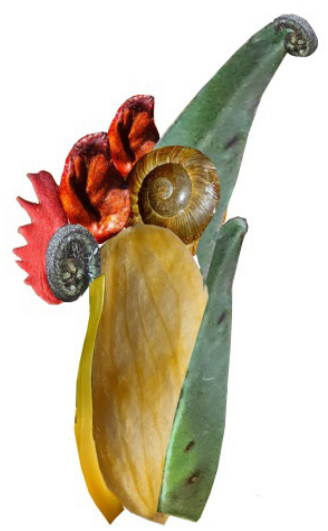

Gambar 19. Simulasi Unsur-Unsur Sumber Inspirasi Patra Punggel

(Sumber: I Nyoman Suardina) tumbuhan yang sangat familiar dan sering ditemukan di alam/lingkungan tempat tinggal. Jika dikonstruksi secara modern dengan teknik grafis, dengan tata letak yang disesuaikan dengan sket Patra Punggel pada gambar sebelumnya, maka akan didapat bentuk seperti pada gambar 9 .

Telaah yang merupakan variabel aktif dalam judul artikel ini dimaksudkan untuk mengurai suatu gejala terkait dengan inertekstualitas dalam proses terwujudnya bentuk Patra Punggel. Berikut akan dijelaskan secara visual gejala yang akan diungkap dalam transformasi dari unsur-unsur alamiah binatang dan tumbuh-tumbuhan menjadi bentuk Patra Punggel.

Analisis terhadap objek kajian dalam Perspektif Metodologi menggunakan simulasi sederhana dengan cara mengkonstruksi unsur-unsur, sehingga diperoleh pendekatan bentuk yang sebelumnya tidak terbayangkan. Berdasarkan simulasi yang dilakukan, tampak jelas hasilnya menyerupai bentuk ukiran Patra Punggel, dengan demikian asumsi awal serta penjelasan dari referensi yang ada, maupun keterangan dari informan mendekati kebenaran.

Simulasi ini juga telah menjawab tujuan dan permasalahan penelitian, yakni mengungkap adanya gejala intertekstualitas dalam penciptaan motif ragam hias Patra Punggel. Interteks memungkinkan seniman untuk mengonstruksi sesuatu yang sebelumnya tidak ada saling keterkaitan, menjadi suatu bentuk baru, dengan makna baru. Jika dieksplorasi lebih jauh, intertekstualitas dalam berkesenian dapat memberikan jalan untuk menemukan model metode penciptaan seni visual. 


\section{SIMPULAN}

Berdasarkan bukti tertua terkait populasi sampel dalam penelitian ini, Patra Punggel telah diterapkan pada tahun 1920-an dalam mendekorasi bangunan suci/ tempat peribadatan Umat Hindu di Pura Puseh Desa dan Pura Tirta Empul, Banjar Silakarang, Sukawati, Gianyar.

Eksistensi Patra Punggel di Bali adalah merupakan salah satu bukti untuk menunjukkan tingginya virtousitas para Undagi (Seniman dan Budayawan) Bali pada masa lampau. Virtousitas ini tercermin pula dari gagasan penciptaan karya seni yang tidak pernah berhenti, karena eksplorasi yang dilakukan bersumber dari alam, lingkungan sosial, pengalaman hidup sehari-hari, maupun pengalaman batiniah terkait keagamaan dan spiritualitas sebagai hubungan yang hakiki antara manusia Bali dengan Tuhannya.

Berdasarkan tujuan penelitian ini yakni pembuktian gejala intertekstualitas dalam penciptaan Patra Punggel oleh Sangging Bali masa lampau terungkap dari analisis dan hasil pembahasan yang telah dilakukan. Bukti tertua yang menunjang terdapat dalam populasi sampel, yakni ornamentasi berupa bentuk Patra Punggel yang terdapat pada Bangunan Pura Puseh Desa, Kori Agung Pura Dadia Tangkas Kori Agung, serta Bangunan Pelinggih di Pura Tirta Empul, Br. Silakarang. Wawancara yang dilakukan dengan tokoh budayawan yang terkait dengan populasi sampel penelitian, tokoh akademisi serta rohaniawan yang pada masa mudanya juga merupakan praktisi yang menggeluti bidang Bangunan Tradisional Bali beserta ornamentasinya yang di dalamnya termasuk
Patra Punggel menyatakan kesesuaian dengan asumsi awal penelitian.

Patra Punggel dibentuk dari inspirasi dan pemikiran brilian Seniman (Sangging) Bali di masa lampau dengan cara mengeksplorasi berbagai unsur flora dan fauna Bali di antaranya, biji buah mangga, serabut buah nangka, jengger ayam jago, keong sawah, telinga babi guling, pelepah daun muda, serta daun pakis muda. Unsur tersebut kemudian dipadupadankan dalam bentuk sulur (lenggak lenggok tumbuhan menjalar), sehingga terwujud komposisi yang indah dan monumental secara ornamentik tradisional Bali.

Gejala intertekstualitas yang terjadi dalam proses perwujudan Patra Punggel merupakan sebuah temuan penting yang belum pernah dipermasalahkan secara khusus dalam penelitian terkait yang pernah dilakukan. Gejala ini merujuk pada sebuah metode penciptaan seni tidak tertulis yang dilakukan di masa lampau. Jika model metode seperti ini sudah biasa dilakukan, ada baiknya para penciptaan seni masa kini, utamanya dikalangan mahasiswa bercermin dari daya cipta yang telah dipresentasikan para pendahulu, menggali, mengembangkan, serta menyesuaikan dengan kebutuhan penciptaan seni saat ini. 


\section{DAFTAR PUSTAKA}

Gelebet, I Nyoman, dkk, (1981/1982), Arsitektur Tradisional Daerah Bali, Departemen Pendidikan dan Kebudayaan Proyek Inventarisasi dan Dokumentasi Kebudayaan Daerah, Denpasar.

Hendriyana, H., I Nyoman Darma Putra, Yan yan Sunarya \& Tyas Rinestu (2021). "Respon Kreatif Perajin Pandan dengan Prinsip Desain Berkelanjutan dan Pelestarian Sumber Daya Alam di Pangandaran Jawa Barat". Panggung, 31(3).

Karuni, Ni Kadek, (2013), “Pengaruh Motif Hias Asing Pada Ukir Bangunan Di Gianyar Bali", MUDRA Jurnal Seni dan Budaya, 28(2), ISI Denpasar.

Kudiya, K., Hendriyana, H., \& Budi, E. M. (2021). "Akselerasi Produksi Kain Batik di Musim Penghujan dengan Menggunakan Mesin Fotonik". Panggung, 31(2).

Kuntowijoyo. (2005), Pendekatan Ilmu Sejarah Dalam Ilmu Sejarah, Gramedia Pustaka Utama, Jakarta.

Mudarahayu, M. T., Sedana, I. N., Remawa, A. A. G. R., \& Sariada, I. K. (2021). Estetika Bentuk Busana Pada Lukisan Wayang Kamasan. Panggung, 31(2).

Moleong, (2007), Metodologi Penelitian Kwalitatif, PT Remaja Rosda Karya, Bandung.

Mujiyono, M. (2016). Logika Intertekstual, Dekonstruksi, dan Simulasi dalam Karya Seni Rupa Posmodern: Studi Kasus pada Karya Redesain Kaos Cenderamata Obyek Wisata Religi Demak. Imajinasi: Jurnal Seni, 10(1), 2130.

Piliang, (2003), Hipersemiotika Tapsir Cultural Studies Atas Matinya Makna, Jalasutra, Yogyakarta

Ratna, Nyoman Kutha, (2010), Metode Penelitian Kajian Budaya dan Ilmu Sosial Humaniora Pada Umumnya, Pustaka Pelajar, Yogyakarta.

Ratna, Nyoman Kutha, (2018), Ensiklopedia 2000 Entri Istilah, Biografi, Karya, Metode dan Teori Sastra, Pustaka Pelajar, Yogyakarta
Rohidi, Tjetjep Rohendi, (2011), Metode Penelitian Seni, Cipta Prima Nusantara, Semarang.

Setem, I Wayan, (2021), Kosarupa Bali Kumpulan Istilah, Artefak, Gerakan, dan Tokoh, Prasasti, Denpasar.

Sika, I Wayan, (1983), Ragam Hias Bali, Departemen Pendidikan dan Kebudayaan Direktorat Pendidikan Menengah Kejuruan, Jakarta.

Siwalatri, N. K. A., Prijotomo, J., \& Setijanti, P. (2012). Meaning of ornament in Balinese traditional architecture. Journal of Basic and Applied Scientific Research, 2, 71217127.

Suardana, I Wayan, (2012), Laporan Penelitian "Penerapan Ornamen Baru pada Seni Ukir Bangunan Di Gianyar Bali" ISI Denpasar.

Susanto, Mikke, (2011), Diksi Rupa: Kumpulan Istilah Seni Rupa, Kanisius, Yogyakarta

Utama, I Gede Satria Budi, (2012), "Nilai Seni Ornamen Tradisional Bali", Jurnal Pendidikan Agama dan Seni, Volume 2(1), UNHI Denpasar 